Sains Malaysiana 50(12)(2021): 3719-3732

http://doi.org/10.17576/jsm-2021-5012-21

\title{
Pengoptimuman Parameter bagi Selulosa Tandan Kosong Kelapa Sawit (TKKS) Teresterifikasi
}

(Parameter Optimization on Esterified Oil Palm Empty Fruit Bunch Cellulose (OPEFB))

\author{
Marhaini Mostapha, Fatihah Azamkamal, Kushairi Mohd SalleH*, Umar Adli amran, Sinyee Gan \& \\ SARANI ZAKARIA
}

\begin{abstract}
ABSTRAK
Pengubahsuaian kimia terhadap selulosa tandan kosong kelapa sawit (TKKS) menggunakan agen pengesteran asid etilena diamina tetraasetik (EDTA) dan asid asetik (AA) dengan parameter yang berbeza dikaji dan dioptimumkan. Pada peringkat awal, pulpa TKKS telah dirawat menggunakan empat peringkat pelunturan (D-E-E-D) untuk menghasilkan selulosa TKKS. Seterusnya, selulosa TKKS melalui proses esterifikasi menggunakan AA dan EDTA yang dibantu oleh sistem pemanasan gelombang mikro bagi tujuan penambahbaikan keberkesanan pengesteran. Pengaruh parameter prarawatan terhadap kestabilan termal dan perubahan kumpulan berfungsi dioptimumkan dengan menggunakan reka bentuk komposit pusat (CCD), pemodelan permukaan tindak balas (RSM) diikuti dengan analisis termogravitometri (TGA) dan analisis kumpulan berfungsi (FT-IR). Didapati terdapat perbezaan ketara (produk esterifikasi) berlaku kepada selulosa TKKS yang diubah suai menggunakan EDTA berbanding AA pada suhu yang tinggi. Data RSM menunjukkan suhu, masa, dan kepekatan bahan kimia yang dioptimumkan untuk selulosa-AA adalah pada suhu $90{ }^{\circ} \mathrm{C}$, 46 min dan kepekatan 8.18 , manakala selulosa-EDTA adalah pada suhu $100{ }^{\circ} \mathrm{C}, 70$ min dan kepekatan 0.7. Berdasarkan analisis CCD, keputusan menunjukkan bahawa rawatan selulosa TKKS dengan agen pengesteran EDTA adalah lebih baik berbanding dengan AA.
\end{abstract}

Kata kunci: Asid asetik; EDTA; esterifikasi; RSM; selulosa

\section{ABSTRACT}

Chemical modifications of oil palm empty fruit bunch cellulose (OPEFBC) using ethylenediaminetetraacetic acid (EDTA) and acetic acid (AA) with different parameters were studied and optimized. At the initial stage, OPEFBC pulp was treated using four stages of bleaching stage (D-E-E-D) for production of OPEFBC. Next, the OPEFB cellulose undergo esterification process using AA and EDTA under microwave assisted heating system to further enhance esterification. The influence of pre-treatment parameters on thermal stability and functional group changes were optimized using central composite design (CCD), response surface modelling (RSM) followed by thermogravimetric analysis (TGA) and functional group analysis (FT-IR). The results showed there were significant differences occurred on the modified OPEFB cellulose particularly by EDTA where higher thermal properties were observed with better esterification product with higher modification occurs compared to cellulose treated with AA. The RSM data showed that temperature, time, and chemicals concentrations optimized for cellulose-AA were at $90^{\circ} \mathrm{C}, 46 \mathrm{~min}$, and 8.18 , respectively, while the optimum parameters for cellulose-EDTA were at $100^{\circ} \mathrm{C}, 70 \mathrm{~min}$, and 0.7 concentrations, respectively. Based on CCD analysis, the results showed that $O P E F B C$ cellulose esterified with EDTA agent is better than AA.

Keywords: Acetic acid; cellulose; EDTA; esterification; RSM

\section{PENGENALAN}

Kekurangan sumber air bersih dan masalah pencemaran air yang semakin membimbangkan berpunca daripada kehadiran molekul organik dan zarah lain yang berbahaya dalam air tanpa rawatan. Terdapat beberapa kajian yang mengakibatkan tercetusnya pelbagai kajian penyelidikan dalam pencarian sumber air bersih. Salah satu alternatif yang boleh dilaksanakan untuk menyelesaikan masalah ini adalah dengan rawatan air sisa. Lazimnya, kaedah rawatan air sisa merangkumi teknologi pengoksidaan melalui peronggaan, pengoksidaan fotokatalitik, ozonasi, hidrogen peroksida dan tindak balas kimia Fenton (Asghar et al. 2015; Pan et al. 2018; Razali et al. 2020; Sajab et al. 2016; Yan et al. 2017). Penggunaan hibrid iaitu campuran kaedah 
pengoksidaan termaju telah dikaji untuk meningkatkan rawatan air sisa dengan menghasilkan radikal bebas dan penguraian terhadap pengoksidan dan molekul pencemar. Kaedah ini terbukti berjaya melakukan penukaran sebatian kepada tidak berbahaya atau mineralisasi lengkap. Walau bagaimanapun, kos bagi pengubahsuaian menggunakan teknik hibrid ini sangat mahal kerana memerlukan penggunaan produk sintetik bukan hijau yang tidak boleh diperbaharui dan penggunaan tenaga elektrik yang tinggi untuk rawatan air sisa (Ahluwalia \& Goyal 2007; Mudhoo et al. 2012).

Penggunaan bahan berasaskan biojisim untuk rawatan air sisa telah banyak diterokai oleh sebab sifatnya yang terbiodegradan, mesra alam, menjimatkan kos serta penggunaan tenaga yang lebih rendah yang menjadi fokus utama dalam mempromosikan teknologi hijau (Abd Wafti et al. 2017; Ibrahim et al. 2017; Saad et al. 2020). Di Malaysia, peningkatan kawasan perkebunan dan aktiviti penghasilan minyak sawit telah meningkatkan sisa biojisim kelapa sawit sekitar 51.19 tan metrik (Mt) dan TKKS pula sekitar 20-23\% daripada jumlah besar sisa biojisim, namun ia masih kurang digunakan atau diterokai (Hamzah et al. 2019; Rahayu et al. 2019). Oleh itu, penggunaan semula serabut biojisim TKKS yang mempunyai kandungan selulosa sebanyak $23.70 \%$, $21.60 \%$ hemiselulosa, $29.20 \%$ lignin dilihat sebagai langkah yang mapan dan hijau (Samiran et al. 2015). Namun, serabut ini perlu dirawat dan melalui proses pengesteran sebagai salah satu langkah penyediaan biobahan untuk teknologi rawatan air sisa. Pengubahsuaian kimia adalah perlu kerana struktur selulosa yang sangat kompleks dengan kehadiran lignin, struktur rantaian yang mempunyai ikatan intra dan intermolekul yang kuat, strukturnya yang stabil serta sukar untuk dilarutkan (Yao \& Wang 2018). Kaedah rawatan yang sesuai dapat mengubah struktur kimia selulosa yang membolehkan ia digunakan dalam inovasi dan teknologi terbaharu yang lebih mesra alam untuk penghasilan produk seperti biosensor urea daripada pengubahsuaian selulosa nano (Khalid et al. 2018), penghasilan membran penapis ultra daripada selulosa fiber melalui pengubahsuaian permukaan selulosa (Fathilah \& Othaman 2019; Gan et al. 2015; Sajab et al. 2017), penghasilan nano-komposit selulosa-polivinilklorida dengan sifat regangan yang ditingkatkan (Sheltami et al. 2015) dan penghasilan komposit berseni yang kukuh melalui pengubahsuaian fizikal dan kimia serat tumbuhan (Ahmad et al. 2019). Pengubahsuaian kimia selulosa secara konvensional melibatkan penggunaan media multifasa dengan gabungan pelbagai jenis pelarut diperlukan. Hal ini kerana sukar untuk mencari gabungan pelarut yang berkesan untuk pengubahsuaian selulosa serta melibatkan proses yang kompleks, ketidakseragaman produk terhasil, kesukaran dalam mengawal struktur dan penggunaan tenaga yang tinggi (Yao \& Wang 2018). Pengubahsuaian selulosa secara esterifikasi adalah lebih mudah dan pantas serta berpotensi untuk menyerap logam berat dalam bahan pencemar air melalui kebolehan pengkelatannya. Asid etilenediaminetetraasetik (EDTA) dan asetik asid (AA) merupakan antara bahan kimia yang digunakan untuk pengubahsuaian kimia secara pengesteran terhadap selulosa (Azamkamal et al. 2018).

Penggunaan gelombang mikro dalam proses pengesteran selulosa dengan EDTA dan AA memberikan pemanasan yang berkesan serta mengurangkan kemusnahan kepada struktur selulosa (Baiya et al. 2019; Englert et al. 2016). Pengubahsuaian kimia tersebut akan mengurangkan berat molekul selulosa secara menggalakkan pemutusan rantaian atau ikatan $\beta-1,4$ rantai glukopiranosa pada selulosa (Qaiser et al. 2010; Sakaguchi et al. 2010). Beberapa kajian lepas melaporkan pengubahsuaian kimia yang dilakukan terhadap selulosa bagi penjanaan semula dalam bentuk hidrogel, gel udara, membran, kertas nano, komposit atau fiber (Anuar et al. 2019; Mazlan et al. 2019; Salleh et al. 2018; Senna et al. 2015, 2014; Yagyu et al. 2015; Zhou et al. 2020).

Parameter seperti masa tindak balas, suhu dan kepekatan agen esterifikasi adalah penting kerana ia mempengaruhi keberkesanan pengubahsuaian kimia selulosa. Penggunaan parameter ini telah banyak dikaji namun pengoptimuman pengubahsuaian kimia selulosa TKKS menggunakan agen pengesteran AA dan EDTA kurang dilaporkan. Dalam kajian ini, RSM telah digunakan untuk meramal parameter optimum serta menjangkakan faktor yang mempengaruhi pengesteran selulosa TKKS berdasarkan parameter yang dikaji. Objektif kajian ini adalah untuk menilai dan mengoptimumkan potensi agen pengesteran EDTA dan AA terhadap selulosa menggunakan rawatan gelombang mikro. Hasil keputusan kajian ini dapat meramalkan parameter optimum bagi pengubahsuaian kimia selulosa TKKS yang berkesan.

\section{KAEDAH KAJIAN}

Pulpa TKKS yang dibekalkan oleh Eko Pulp dan Paper, Malaysia telah digunakan sebagai bahan asas dalam kajian ini. Serabut TKKS telah dikisar menggunakan pengisar bebola kepada saiz 60-70 mesh. $\mathrm{NaOH}$ telah digunakan sebagai agen pembengkakan, manakala AA dan EDTA sebagai agen esterifikasi. Bahan-bahan ini dibekalkan oleh R\&M dan digunakan tanpa penulenan.

\section{PROSES PELUNTURAN}

Proses perlunturan dilakukan sebagaimana yang dilaporkan dalam Salleh et al. (2018). Pulpa TKKS telah diluntur menggunakan empat peringkat pelunturan (D-EE-D) dengan D adalah proses pelunturan yang terdiri 
daripada 1.7 bt.\% natrium klorit $\left(\mathrm{NaClO}_{2}\right)$ dan pada 80 ${ }^{\circ} \mathrm{C}$ selama 2 jam. Rawatan alkali (E) dilakukan dengan menggunakan larutan 4-6 bt.\% $\mathrm{NaOH}$ pada suhu $80{ }^{\circ} \mathrm{C}$ selama $30 \mathrm{~min}$. Sampel dibasuh dengan air suling selepas setiap peringkat dan ditapis menggunakan penapis kain sehingga neutral. Akhir sekali, pulpa TKKS dikeringkan dalam relau selama 24 jam pada suhu $105^{\circ} \mathrm{C}$ dan disimpan di tempat kering. Sampel ini dikenali sebagai selulosa TKKS.

\section{PROSES PENGUBAHSUAIAN}

Selulosa TKKS melalui proses pengubahsuaian kimia dengan rawatan menggunakan AA menghasilkan selulosa-AA, dengan AA mempunyai 1 kumpulan karboksilik $(\mathrm{COOH})$ dan rawatan dengan EDTA yang mempunyai 4 kumpulan $\mathrm{COOH}$, menghasilkan selulosaEDTA. Bagi pengubahsuaian kimia menghasilkan selulosa-AA, sebanyak $5 \mathrm{~g}$ berat kering selulosa TKKS ditambah dengan $200 \mathrm{~mL}$ AA 5-20\% (bt.\%), manakala bagi pengubahsuaian selulosa-EDTA, sebanyak $5 \mathrm{~g}$ berat kering selulosa TKKS ditambah dengan $200 \mathrm{~mL}$ 0.4-1.0 (bt.\%) EDTA. Bagi kedua-dua rawatan pengubahsuaian selulosa TKKS, sistem pemanasan gelombang mikro digunakan yang ditetapkan pada kuasa $100 \mathrm{~W}$ selama 20-120 min pada suhu 25-120 ${ }^{\circ} \mathrm{C}$ (Jadual 1). Keadaan pemalar dan parameter optimum ditentukan dengan CCD dengan menggunakan model RSM. Selulosa yang telah dirawat kemudiannya ditapis menggunakan kertas turas dengan saiz liang $20 \mu \mathrm{m}$ dan dibasuh menggunakan air suling bagi membuang lebihan AA dan EDTA. Selulosa yang diubah suai seterusnya dikeringkan pada $80{ }^{\circ} \mathrm{C}$ di dalam relau semalaman dan disimpan untuk analisis selanjutnya.

\section{PENCIRIAN DAN UJI KAJI SELULOSA TERUBAH SUAI SPEKTROSKOPI INFRAMERAH FOURIER TRANSFORMASI (FT-IR)}

FT-IR kaedah ATR telah digunakan secara kaedah kuantitatif. Sebanyak $100 \mathrm{mg}$ sampel dianalisis menggunakan perisian OPUS 7.5, Alpha II, Bruker dari Amerika Syarikat. Nombor gelombang yang diukur antara 4000 - $800 \mathrm{~cm}^{-1}$ dengan pengimbasan $32 \mathrm{kali}$. Dalam kajian ini, FT-IR diaplikasikan untuk menganalisis kumpulan berfungsi yang terkandung pada selulosa setelah dirawat dengan menggunakan asetik asid pada kepekatan 5, 10, 15 dan 20\% manakala EDTA pada kepekatan $0.4,0.6,0.8$ dan $1.0 \%$.

\section{ANALISIS TERMOGRAVIMETRI (TGA)}

Analisis termogravimetri dijalankan menggunakan mesin Mettler Toledo TGA model SDTA 851e thermobalance. Sebanyak $10 \mathrm{mg}$ sampel pada kadar pemanasan $10^{\circ} \mathrm{C} \mathrm{min}{ }^{-1}$ daripada julat suhu 25 hingga $600{ }^{\circ} \mathrm{C}$ dalam atmosfera nitrogen. Pencirian ini dijalankan bagi mengetahui kestablian termal sampel setelah diubah suai.

\section{PENGOPTIMUMAN PARAMETER REAKSI ESTERIFIKASI MELALUI RSM}

Pemodelan permukaan tindak balas (RSM) ini dijalankan menggunakan Design Expert ${ }^{\circledR}$ Tools untuk menghasilkan model dan memilih parameter optimum bagi pengubahsuaian kimia selulosa TKKS. Model dibentuk dengan menggunakan parameter sebagai faktor $\mathrm{X}_{1}=$ suhu, $\mathrm{X}_{2}=$ masa dan $\mathrm{X}_{3}=$ kepekatan AA dan EDTA. Julat suhu yang dipilih adalah antara 25 hingga $120^{\circ} \mathrm{C}$, masa rawatan adalah pada 20 hingga 120 min manakala kepekatan pada 5 hingga 20\% (EDTA) dan 0.4 hingga $1.0 \%$ (AA). Data reka bentuk uji kaji yang dianalisis menggunakan RSM adalah seperti pada Jadual 1.

Kemudian, rawatan TKKS terhadap parameter tersebut telah dilakukan di dalam makmal mengikut reka bentuk untuk mencapai tindak balas sebenar, $\alpha$. Respons ini digunakan untuk model bagi mengoptimumkan faktor-faktor dengan kaedah RSM. Tindak balas sebenar telah dipadankan ke dalam persamaan polinomial aljibra tertib kedua yang sah sebagai model kuadratik. Model kuadratik telah dicadangkan untuk diselidiki dengan menggunakan analisa varians (ANOVA) berdasarkan beberapa pengesahan statistik seperti sisihan piawai terendah, nilai-P, PRESS dan nilai tertinggi Radj, Rpred. Model optimum menentusahkan faktor-faktor sama ada melalui persamaan kanonikal atau plot 3D sebagai titik optimum kawasan permukaan. Langkah RSM terdiri daripada: menyelesaikan reka bentuk uji kaji dengan mengukur respons untuk setiap uji kaji; penentuan model urutan kedua matematik (model kuadratik); mencari keadaan optimum untuk mengoptimumkan suhu rawatan, kepekatan dan masa rawatan dalam menghasilkan maksimum $\alpha$ dengan profil rawatan minimum dan yang mewakili kesan pemboleh ubah terhadap tindak balas oleh plot 3D.

\section{KePUTUSAN DAN PERBINCANGAN}

\section{REKA BENTUK KOMPOSIT PUSAT (CCD) DENGAN PEMODELAN KAEDAH PERMUKAAN TINDAK BALAS (RSM)}

Pengoptimuman selulosa TKKS terubah suai iaitu selulosa-AA (Jadual 2) dan selulosa-EDTA (Jadual 3) telah dianalisa menggunakan CCD dengan RSM. Hubungan antara pemboleh ubah bersandar dan set pemboleh ubah boleh malar dalam RSM ditunjukkan oleh polinomial urutan kedua seperti yang ditunjukkan dalam (1) untuk AA dan (2) untuk EDTA:

$$
\begin{aligned}
\alpha= & -4.12894+0.128039 X_{1}+0.0550872 X_{2}+0.157346 \\
& X_{3}+0.000273676 X_{1} X_{2}+0.00259005 X_{1} X_{3}- \\
& 0.000493839 X_{2} X_{3}+-0.00114657 X_{12}-0.000402935 \\
& X_{2}^{2}-0.00748415 X_{3}^{2}
\end{aligned}
$$


JADUAL 1. Reka bentuk uji kaji pemodelan permukaan tindak balas (RSM) menentukan parameter optimum bagi pengubahsuaian TKKS menggunakan EDTA dan AA

\begin{tabular}{|c|c|c|c|}
\hline \multicolumn{4}{|c|}{ EDTA } \\
\hline Sampel & Suhu $\left({ }^{\circ} \mathrm{C}\right)$ & Masa (Min) & Kepekatan (\%) \\
\hline 1 & 75.00 & 70.00 & 12.50 \\
\hline 2 & 75.00 & 70.00 & 12.50 \\
\hline 3 & 75.00 & 70.00 & 12.50 \\
\hline 4 & 75.00 & 70.00 & 5.00 \\
\hline 5 & 25.00 & 20.00 & 20.00 \\
\hline 6 & 25.00 & 120.00 & 5.00 \\
\hline 7 & 120.00 & 70.00 & 12.50 \\
\hline 8 & 75.00 & 20.00 & 12.50 \\
\hline 9 & 25.00 & 120.00 & 20.00 \\
\hline 10 & 25.00 & 20.00 & 5.00 \\
\hline 11 & 75.00 & 70.00 & 12.50 \\
\hline 12 & 75.00 & 70.00 & 12.50 \\
\hline 13 & 120.00 & 20.00 & 20.00 \\
\hline 14 & 120.00 & 120.00 & 5.00 \\
\hline 15 & 75.00 & 120.00 & 12.50 \\
\hline 16 & 25.00 & 70.00 & 12.50 \\
\hline 17 & 75.00 & 70.00 & 12.50 \\
\hline 18 & 120.00 & 20.00 & 5.00 \\
\hline 19 & 120.00 & 120.00 & 20.00 \\
\hline 20 & 75.00 & 70.00 & 20.00 \\
\hline \multicolumn{4}{|c|}{ Asid Asetik } \\
\hline Sampel & Suhu $\left({ }^{\circ} \mathrm{C}\right)$ & Masa (Min) & Kepekatan (\%) \\
\hline 1 & 100.00 & 20.00 & 0.40 \\
\hline 2 & 25.00 & 120.00 & 1.00 \\
\hline 3 & 62.50 & 70.00 & 0.20 \\
\hline 4 & 62.50 & 154.09 & 0.70 \\
\hline 5 & 62.50 & 70.00 & 0.70 \\
\hline 6 & 62.50 & 70.00 & 0.70 \\
\hline 7 & 62.50 & 70.00 & 0.70 \\
\hline 8 & 120.00 & 70.00 & 0.70 \\
\hline 9 & 62.50 & 70.00 & 0.70 \\
\hline 10 & 62.50 & 20.00 & 0.70 \\
\hline 11 & 100 & 120.00 & 0.70 \\
\hline 12 & 25.00 & 70.00 & 0.40 \\
\hline 13 & 100.00 & 120.00 & 0.70 \\
\hline 14 & 25.00 & 20.00 & 1.00 \\
\hline 15 & 62.50 & 70.00 & 0.70 \\
\hline 16 & 62.50 & 70.00 & 1.00 \\
\hline 17 & 62.50 & 70.00 & 0.70 \\
\hline 18 & 25.00 & 20.00 & 0.40 \\
\hline 19 & 25.00 & 120.00 & 0.40 \\
\hline 20 & 100.00 & 20.00 & 1.00 \\
\hline
\end{tabular}


JADUAL 2. CCD pengubahsuaian TTKS selulosa-AA pada parameter yang berlainan

\begin{tabular}{lcccc}
\hline Parameter & Nilai berkod & \multicolumn{3}{c}{ Tahap / julat / jenis } \\
\hline Angka & & -1 & 0 & 1 \\
Suhu & $\mathrm{X}_{1}$ & 25 & 75 & 100 \\
Masa & $\mathrm{X}_{2}$ & 20 & 70 & 120 \\
Kepekatan & $\mathrm{X}_{3}$ & 5 & 13 & 20 \\
\hline
\end{tabular}

$$
\begin{aligned}
\alpha= & -5.37183+0.0802968 X_{1}+0.0426621 X_{2}+18.1121 X_{3}+ \\
& 0.000325467 X_{1} X_{2}+0.0611111 X_{1} X_{3}+0.0131167 X_{2} X_{3} \\
& -0.000918368 X_{1}^{2}-0.000417382 X_{2}^{2}-14.2051 X_{3}^{2}
\end{aligned}
$$

\section{VALIDASI MODEL}

RSM adalah proses kajian berturutan yang merangkumi tiga fasa reka bentuk. Fasa pertama yang dipanggil

\begin{tabular}{|c|c|c|c|c|}
\hline Parameter & Nilai berkod & \multicolumn{3}{|c|}{ Tahap / julat / jenis } \\
\hline Angka & & -1 & 0 & 1 \\
\hline Suhu & $\mathrm{X}_{1}$ & 25 & 75 & 100 \\
\hline Masa & $\mathrm{X}_{2}$ & 20 & 70 & 120 \\
\hline Kepekatan & $\mathrm{X}_{3}$ & 0.4 & 0.7 & 1.0 \\
\hline
\end{tabular}
sebagai kajian penyaringan, direka untuk mencari faktor

JADUAL 3. CCD pengubahsuaian TTKS selulosa-EDTA pada parameter yang berlainan

$\alpha$ - persamaan bagi mencapai tindak-balas sebenar

yang diperlukan dan mengurangkan bilangan pemboleh ubah reka bentuk. Hal ini adalah langkah awal untuk membuat percubaan berikutnya supaya pemboleh ubah yang digunakan lebih sesuai dan tepat. Fasa kedua menggunakan kaedah kecerunan graf paling curam terutamanya pada model permukaan tindak balas pertama untuk mengoptimumkan proses. Matlamatnya adalah untuk mengkaji tindak balas keadaan optimum dengan menyesuaikan pemboleh ubah yang penting. Apabila sistem atau proses menghampiri keadaan optimum, reka bentuk fasa ketiga diteruskan untuk menentukan keadaan proses yang optimum. Model permukaan tindak balas kedua pula digunakan pada fasa ketiga untuk memperkenalkan kelengkungan ke dalam fungsi tindak balas dan mendapatkan anggaran yang tepat.

Sebelum memulakan analisis, model yang bersesuaian telah dipilih untuk menjalankan uji kaji reka bentuk data. Keputusan data ditunjukkan oleh beberapa plot diagnostik yang digunakan untuk memeriksa model. Rajah 1(a) \& 1(b) menunjukkan plot kebarangkalian normal sisa pelajar yang merupakan salah satu daripada pelbagai plot diagnostik yang memeriksa normal, ralat berterusan dan penjelasan sisa. Jika sisa-sisa bertaburan secara normal, sisa tersebut berada dalam kedudukan yang selaras. Seperti yang diperhatikan, peratusan plot kebarangkalian adalah normal dan menunjukkan bahawa sisihan dari garis lurus adalah sangat kecil dan ia menyokong model adalah normal. Oleh itu, plot menunjukkan bahawa sisa dan data mengikut taburan normal dan dalam garis lurus.

ANOVA digunakan untuk pengesahan dan menguji kepentingan model yang sesuai. Menurut nilai kebarangkalian (model p) nilai ujian $\mathrm{F}$ yang sangat rendah, $\mathrm{X}_{1}$ boleh disifatkan sebagai sangat signifikan. Nilai pekali regresi yang tinggi dan taburannya menunjukkan kemampuan model $\mathrm{X}_{1}$ untuk menggambarkan taburan dalam julat parameter yang dikaji. Pemilihan model merupakan salah satu daripada cara untuk memeriksa normaliti, kesilapan berterusan dan sempadan lebihan yang berlaku pada data plot. Jika taburan sisa secara 
normal, semua titik akan berada dalam kedudukan selaras dan ia menyokong hipotesis model adalah normal (Bewick 2003). Seperti yang dapat dilihat daripada Rajah 1 dan 2, model membentangkan korelasi kobs rawatan yang dikaji dan nilai-nilai sampel yang diramalkan oleh $\mathrm{X}_{1}$, titik-titik berada dalam garis penjuru akibat daripada perbezaan yang rendah sehingga nilai sisa juga rendah. Ujian kebarangkalian bagi kebarangkalian normal ditunjukkan dalam Rajah 2. Titik terletak rapat dengan garis pepenjuru, menunjukkan bahawa tiada pelanggaran serius dalam anggapan bahawa ralat berlaku secara normal dan bebas antara satu sama lain yang bersifat homogen dan bebas. Anggapan ini bahawa varian tetap sisa diuji dengan merancang sisa secara

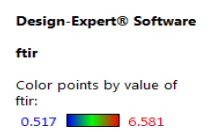

a)

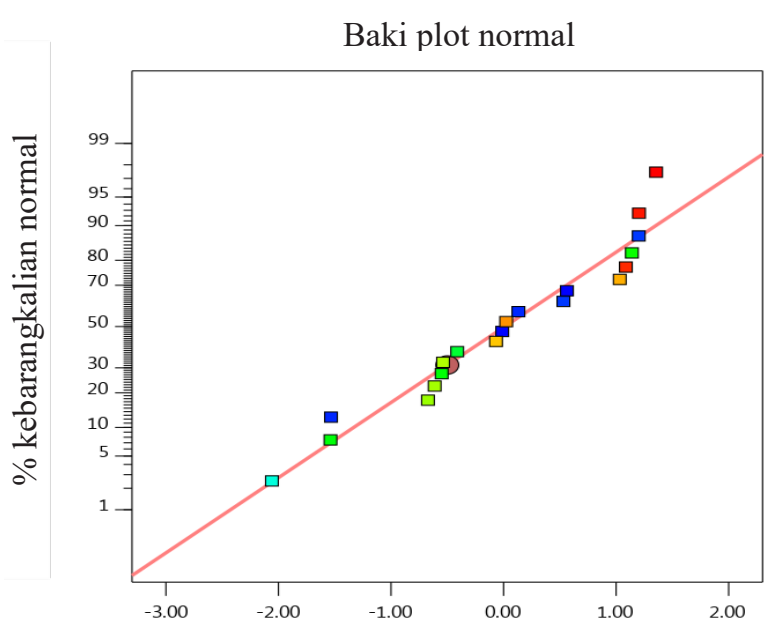

Baki terpelajar luaran

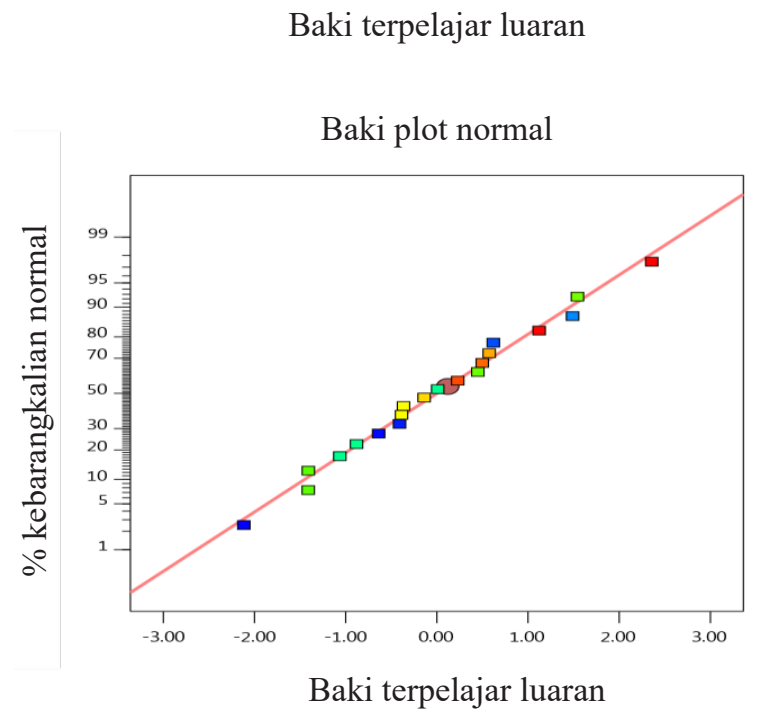

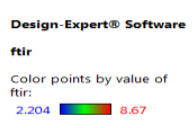

b)

RAJAH 1. Model validasi bagi selulosa TKKS terubah suai (a) selulosa-

AA dan (b) selulosa-EDTA

tertumpu berbanding dengan nilai yang dijangkakan. Hal ini dapat dilihat bahawa titik-titik tersebut bertaburan dan semua nilai adalah antara had pengesanan luar dan bawah, -2 dan +2 . Analisis sisa menggambarkan bahawa normaliti dan model berjaya membentuk korelasi antara parameter yang mempengaruhi sistem kajian. Titik berada berhampiran dengan garis lurus menunjukkan bahawa tidak ada pelanggaran serius dalam anggapan bahawa variasi ralat adalah homogen.

Kontur FT-IR 3D menunjukkan kesan hubungan antara masa $(\mathrm{min})$ dan suhu $\left({ }^{\circ} \mathrm{C}\right)$ pada kumpulan berfungsi selulosa TKKS semasa peningkatan dan pengesteran 
menggunakan AA (3(a)) dan EDTA (3(b)). Trend yang serupa diperhatikan untuk kesan masa apabila peningkatan menggunakan AA dan EDTA dengan masa tindak balas yang lebih pendek (20-40 min) dan lebih tinggi 80-120 min menghasilkan perubahan FT-IR kurang (skor $=0$ untuk AA, skor $=4$ untuk EDTA) (Rajah 3(a) \& 3(b)). Hal ini mungkin disebabkan oleh masa dan suhu tindak balas yang lebih rendah menyebabkan sampel kurang reaktif. Perubahan FT-IR yang lebih rendah dan suhu yang lebih tinggi menyebabkan dehidrasi dan pendepolimeran selulosa yang dikenali sebagai tahap kebolehan penguraian selulosa (Rantuch et al. 2014). Walau bagaimanapun, pemanasan pada 40-60 min lebih tinggi, perubahan kumpulan berfungsi telah direkodkan (skor=1 untuk AA, skor $=4$ untuk EDTA). Sebagai perbandingan, pengubahsuaian kimia dengan EDTA menunjukkan prestasi yang lebih baik dan kesan yang signifikan terhadap pengubahsuaian kumpulan berfungsi berbanding AA. Maksimum plot sepadan dengan skor kualiti tertinggi 4 berlaku pada 90 ${ }^{\circ} \mathrm{C}$, 46 min dan kepekatan AA 8.18\%, sementara untuk

a)

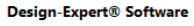

ftir

Color points by value of

ftir: 0.59 b)
Design-Expert@ Software

Color points by value of

$2.204 \square 8.67$
Baki vs. jangkaan

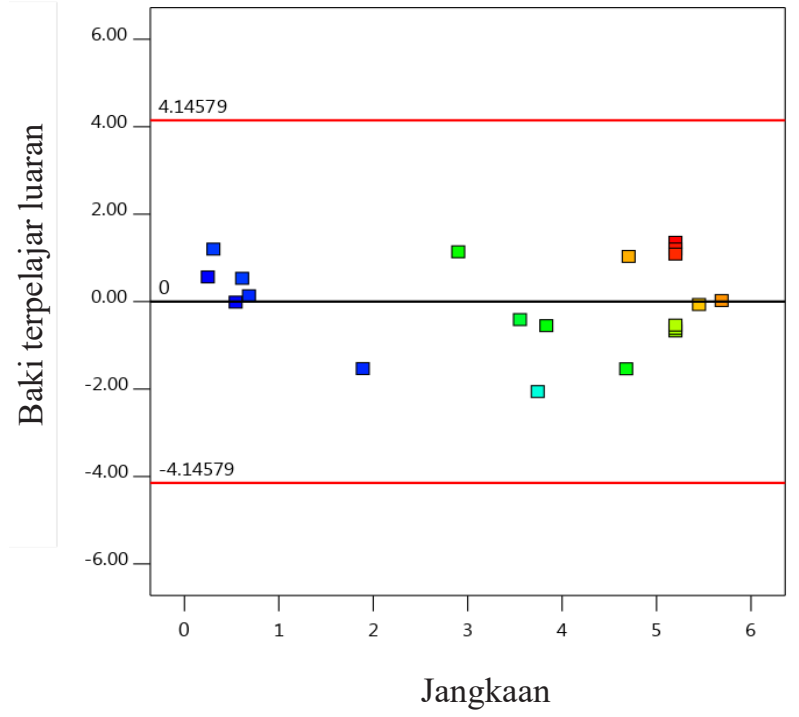

Baki vs. jangkaan

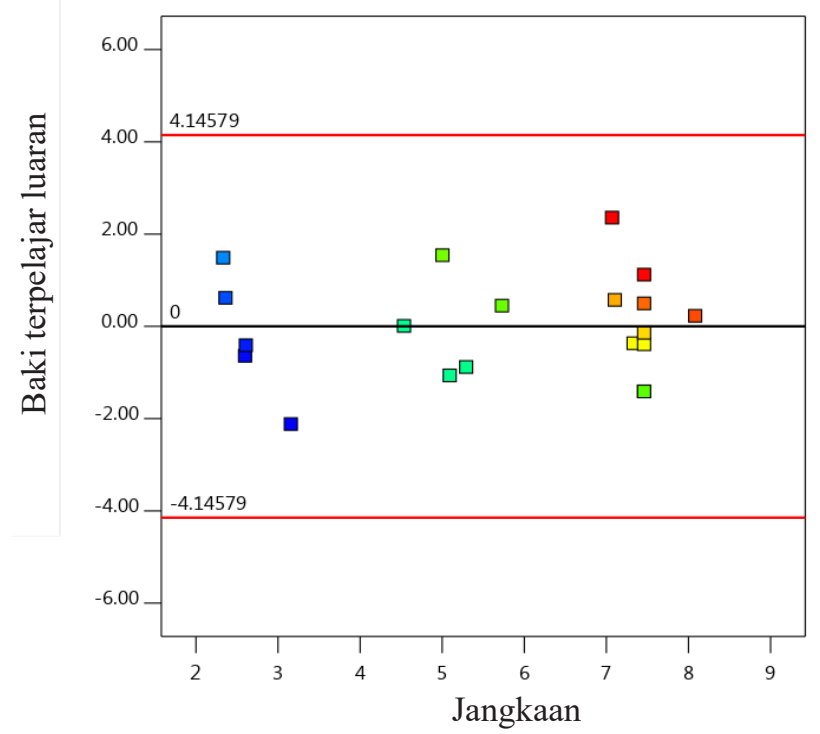

RAJAH 2. Sisa taburan dan jangkaan selulosa TKKS terubah suai (a) selulosaAA dan (b) selulosa-EDTA bagi kumpulan berfungsi yang terpilih 

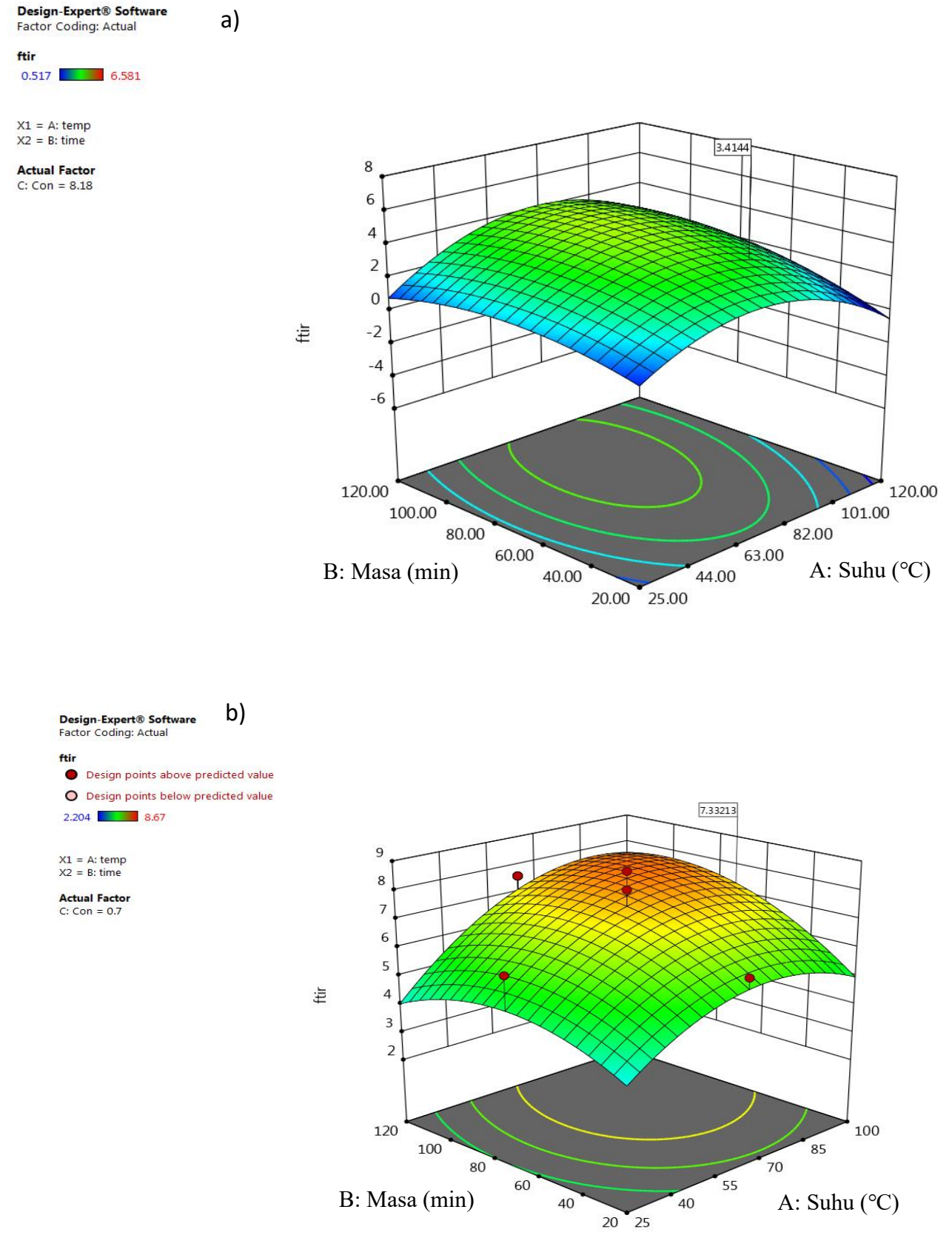

RAJAH 3. 3D plot selulosa TKKS terubah suai (a) selulosa-AA dan (b) selulosa-EDTA berdasarkan parameter masa, suhu dan kepekatan bagi kumpulan berfungsi yang terpilih

EDTA pada $100{ }^{\circ} \mathrm{C}, 70$ min dan kepekatan $0.70 \%$ dengan skor kualiti 7 (Rajah 4).

Melalui proses esterifikasi, RSM meramalkan bahawa 3.41 selulosa TKKS (perubahan spektrum FTIR) pada $89.98{ }^{\circ} \mathrm{C}$ selama 45.58 min dengan 8.18 adalah parameter yang dioptimumkan untuk AA. Sementara itu, perubahan spektrum FT-IR yang lebih tinggi sekitar 7.33 dapat dicapai dengan kepekatan jauh lebih rendah 0.7 EDTA pada suhu $100{ }^{\circ} \mathrm{C}$ selama $70 \mathrm{~min}$. Sebagai perbandingan, parameter pengoptimuman untuk pengesteran selulosa TKKS menggunakan EDTA sangat mempengaruhi spektrum FT-IR berbanding AA. Hal ini 
mungkin disebabkan oleh EDTA yang mengandungi 4 kumpulan $\mathrm{COOH}$, sehingga memberikan kemampuan pengelatan yang lebih tinggi dibandingkan dengan AA yang mempunyai 1 kumpulan $\mathrm{COOH}$ (Daneshfozouna et al. 2014).

a)
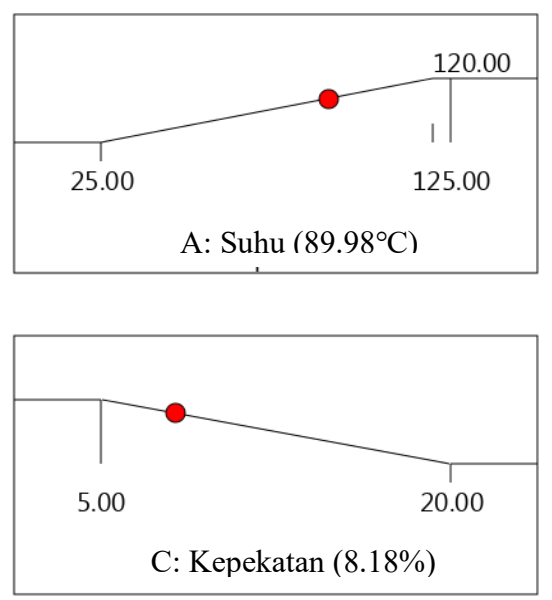

Kebolehinginan $=0.662$

b)
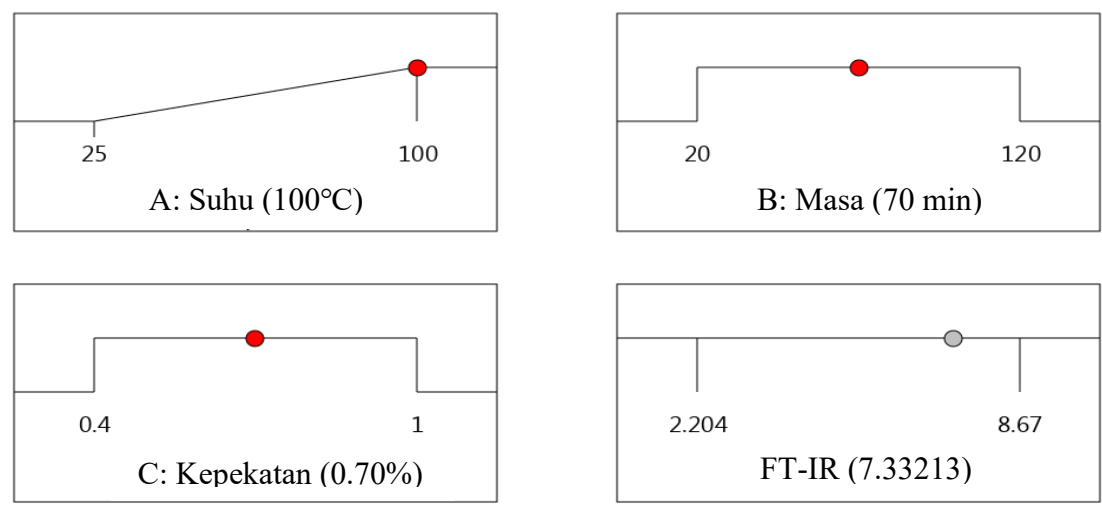

Kebolehinginan $=1.000$

\section{ANALISIS KUMPULAN BERFUNGSI TERHADAP TKKS YANG DIUBAH SUAI}

Dalam kajian ini, FT-IR dilakukan untuk menganalisis perbezaan kumpulan berfungsi yang wujud pada selulosa terubah suai tersebut sebelum pelekatan pada ion dijalankan. Berdasarkan kajian lepas, kumpulan $\mathrm{COOH}$ boleh dilihat pada selulosa terubah suai yang telah dirawat dengan asetik asid dan EDTA. Rajah 5 menunjukkan
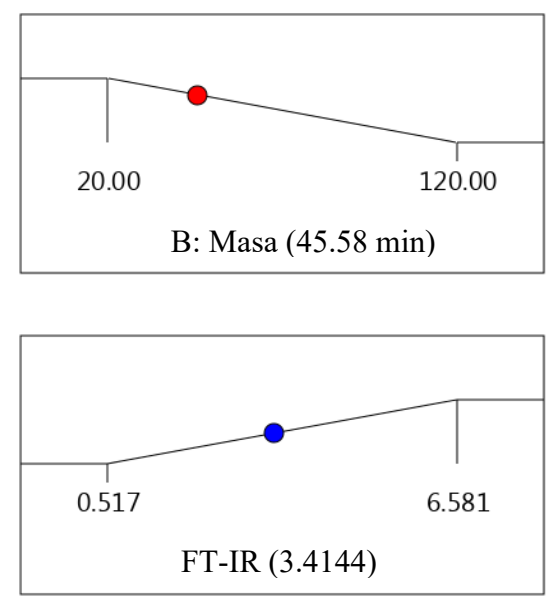

FT-IR (3.4144)

RAJAH 4. Pengoptimuman selulosa TKKS terubah suai (a) selulosa-AA dan (b) selulosa-EDTA

spektrum FT-IR selulosa TKKS yang telah dirawat dengan peratusan AA yang berbeza (5 hingga 20 bt.\%) dan EDTA (0.4 hingga 1.0 bt.\%). Berikut menunjukkan puncak jalur penyerapan baru dalam spektrum FT-IR bagi reaksi esterifikasi selulosa-AA dan selulosa-EDTA.
Berdasarkan spektrum FT-IR yang dihasilkan, Rajah 5 menunjukkan puncak yang kuat pada $1028 \mathrm{~cm}^{-1}$ merujuk kepada mod glisosidik pada ikatan cincin merujuk kepada berlakunya regangan $\mathrm{C}-\mathrm{O}$ pada polisakarida untuk kedua-dua rawatan. Peningkatan keamatan puncak pada 1320 hingga $1337 \mathrm{~cm}^{-1}$ merujuk kepada 
penambahan kumpulan berfungsi $-\mathrm{CH}_{2}$ pada selulosa kristal dan -OH dalam selulosa amorf (Stevulova et al. 2014). Peningkatan jalur penyerapan pada 1710-1610 $\mathrm{cm}^{-1}$ ditunjukkan dalam getaran regangan $\mathrm{C}=\mathrm{O}$ asid karboksilik sebagai jalur rujukan (Smith et al. 2018). Daripada pemerhatian, keamatan puncak yang lebih tinggi muncul pada $1621 \mathrm{~cm}^{-1}$ untuk selulosa TKKSEDTA berbanding dengan selulosa-AA, dengan spektrum memberikan penambahan getaran regangan asimetri $\mathrm{C}=\mathrm{O}$ asid karboksilik. Peningkatan keamatan puncak adalah selari dengan peningkatan kepekatan bt.\% agen pengesteran. Pembentukan asid karboksilat dalam produk juga dikaji oleh penyerapan khas pada $1709 \mathrm{~cm}^{-1}$ yang terbentuk daripada getaran regangan simetri karbonil (Smith et al. 2018). Ia juga diperhatikan dalam perubahan dan turun naik keamatan puncak pada 2800 hingga 2897 $\mathrm{cm}^{-1}$ yang merujuk kepada berlakunya peregangan simetri polisakarida C-H dan O-H (Smith et al. 2018; Stevulova et al. 2014). Dalam analisis FT-IR ini, dapat disimpulkan

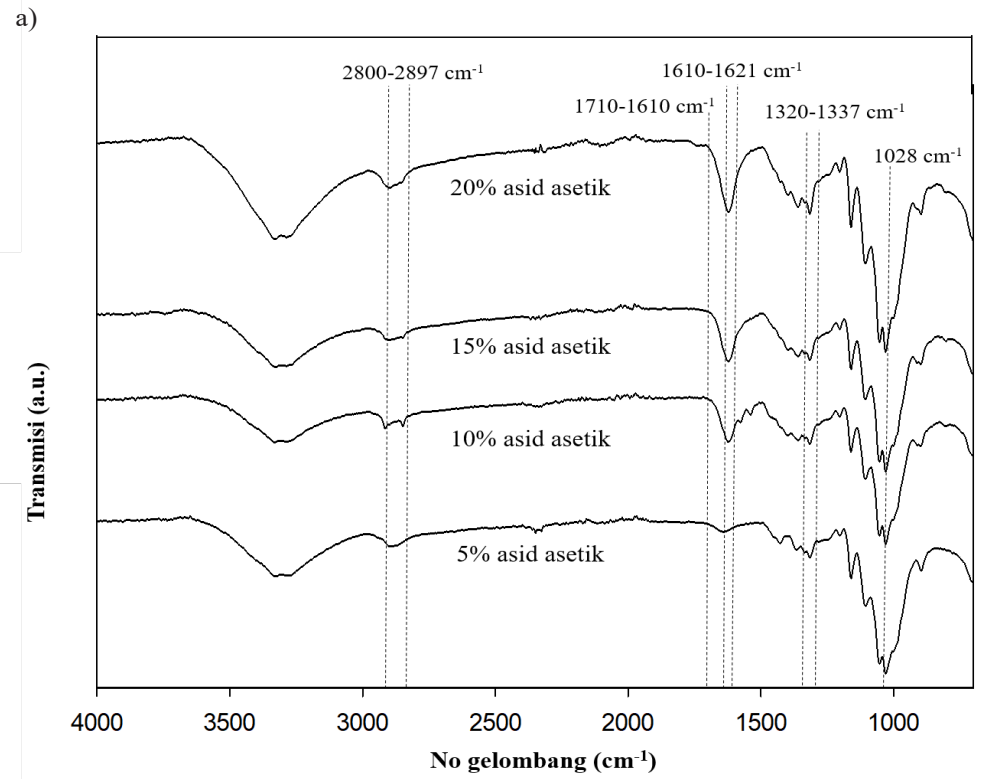

b)

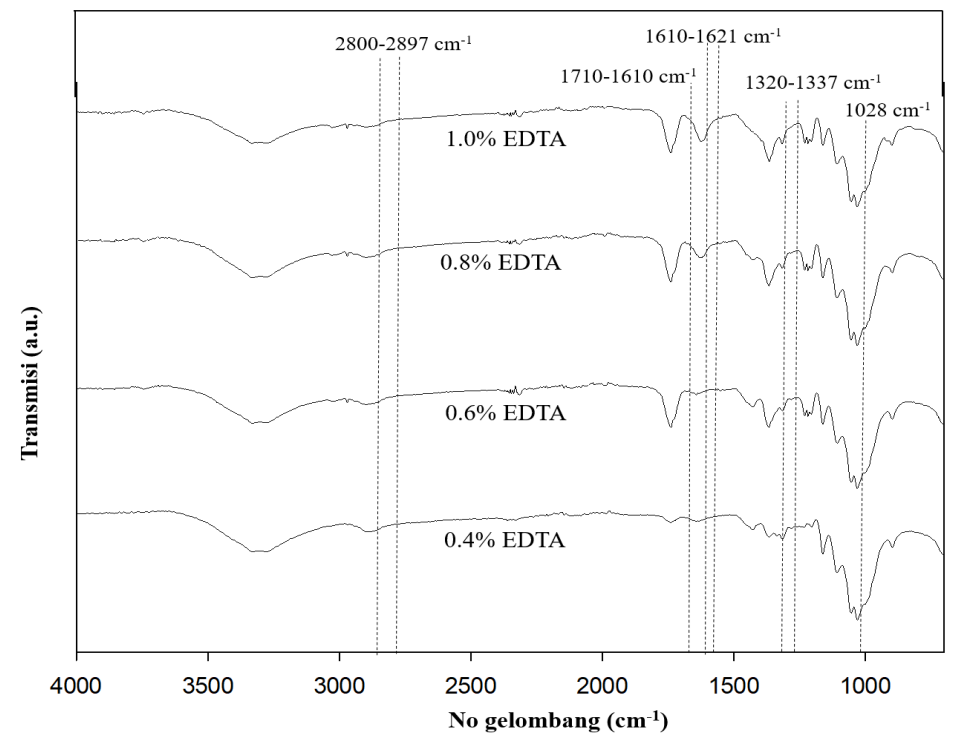

RAJAH 5. FT-IR bagi selulosa TKKS terubah suai a) selulosa-AA (5-20 bt.\%) dan b) selulosa-EDTA (0.4-1.0 bt.\%) 
bahawa kedua-dua rawatan AA dan EDTA berjaya mengubahsuaikan selulosa TKKS. Namun, perubahan keamatan puncak FT-IR yang lebih tinggi bagi selulosaEDTA menunjukkan pengubahsuaian yang lebih berkesan berbanding selulosa-AA.

\section{ANALISIS TERMAL TERHADAP TKKS YANG DIUBAH SUAI}

Analisis TGA digunakan untuk mengkaji tingkah laku terma selulosa TKKS yang telah diubah suai dengan kepekatan asid AA dan EDTA yang berbeza seperti yang ditunjukkan dalam Rajah 6(a) dan 6(b). Corak lengkuk TGA bagi selulosa-AA menunjukkan corak yang hampir sama (tiada perbezaan ketara) bagi semua kepekatan yang dirawat (5-20 bt.\%). Sebaliknya, corak lengkuk
TGA yang berbeza diperhatikan untuk selulosa-EDTA pada kepekatan berbeza terutamanya pada 0.6-1.0 bt.\%. Melalui keputusan analisis TGA ini, dapat disimpulkan bahawa kepekatan EDTA yang berbeza mempunyai pengaruh yang lebih tinggi berbanding dengan AA pada profil TGA selulosa TKKS.

Daripada lengkung TGA, semua sampel selulosa TKKS menunjukkan tiga peringkat utama penurunan berat jisim. Penurunan berat jisim pertama berlaku pada 100 hingga 95 bt.\%. Sampel yang berada di bawah $130{ }^{\circ} \mathrm{C}$ (tahap 1), merujuk kepada berlakunya proses pembebasan sebatian mudah meruap, kehilangan kelembapan, kehilangan air serta penyerapan semula air dari kawasan selulosa hablur (de Carvalho Benini et al. 2017). Setelah kehilangan kelembapan awal dan penyerapan gas seperti karbon dioksida, dapat dilihat bahawa selulosa-AA dan selulosa-EDTA kedua-duanya mula merosot berbanding

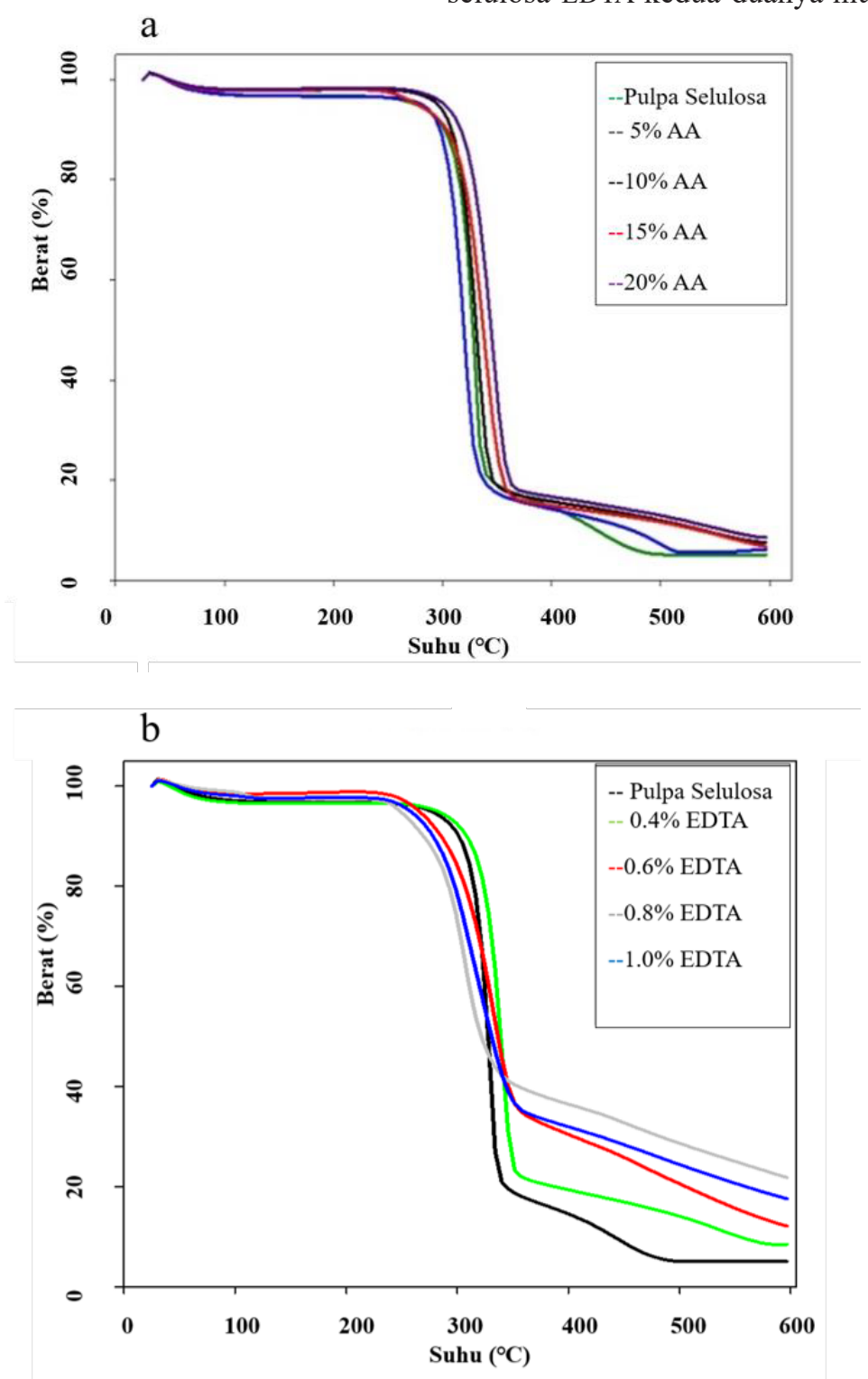

RAJAH 6. Lengkuk termogravitometri selulosa TKKS diubah suai (a) AA dan (b) EDTA 
dengan selulosa pulpa TKKS (Rajah 6(a) \& 6(b)). Hal ini mungkin disebabkan proses pengesteran telah meningkatkan penguraian kawasan amorfus pada rantai selulosa seterusnya menurunkan kestabilan termanya (Jandura et al. 2000).

Pengurangan haba utama dan penurunan berat jisim yang ketara daripada 95 hingga 20 bt.\% berlaku bagi kedua-dua rawatan AA dan EDTA diperhatikan pada julat suhu 250 dan $350{ }^{\circ} \mathrm{C}$ (tahap 2). Bagi lengkuk TGA selulosa-AA, kepekatan rawatan 5 bt.\% merupakan yang pertama terurai, diikuti oleh pulpa selulosa, rawatan 10, 15 dan 20 bt.\% AA. Manakala bagi lengkuk TGA selulosa TKKS yang dirawat dengan EDTA (selulosaEDTA), pengesteran dengan 1\% EDTA adalah yang pertama terurai, diikuti oleh $0.4,0.8$, pulpa selulosa dan $0.6 \%$ EDTA. Keamatan puncak yang tinggi diperhatikan pada peringkat ini yang disebabkan oleh berlakunya pendepolimeran dan penguraian rantaian selulosa TKKS yang mempunyai berat molekul rendah serta penyingkiran unsur-unsur lebihan pada selulosa TKKS termasuk lignin, hemiselulosa dan ekstrak lain (de Carvalho Benini et al. 2017; Le Normand et al. 2014).

Daripada hasil analisis terma yang dijalankan, dapat diperhatikan peratusan pengubahsuaian selulosa-AA yang lebih tinggi telah menyumbang kepada kestabilan terma yang lebih baik berbanding pulpa selulosa TKKS. Sebaliknya, kepekatan pengubahsuaian selulosa-EDTA yang lebih rendah telah menunjukkan kestabilan terma yang jauh lebih tinggi daripada selulosa-AA dan pulpa selulosa. Manakala, pada tahap terakhir (S3), berlaku perubahan lengkuk dan berat \% yang ketara dengan merujuk kepada pendegradan selulosa dan penurunan berterusan berat molekul pada rantai panjang polimer selulosa TKKS yang diubah suai berlaku untuk semua sampel pada suhu 400 hingga $600{ }^{\circ} \mathrm{C}$ (Jandura et al. 2000). Pendegradan lengkap ini dapat diperhatikan pada pulpa selulosa TKKS dan selulosa-AA 5 bt.\% pada suhu $500{ }^{\circ} \mathrm{C}$ dengan hanya tinggal $\pm 5 \%$ sahaja berat akhir diikuti dengan pembentukan arang (Jandura et al. 2000). Sementara itu, untuk sampel lain selulosa TKKS yang diubah suai oleh 10 hingga 20 bt.\% AA dan 0.4 hingga 1.0 bt.\% EDTA hanya menunjukkan penurunan berat jisim yang berterusan dengan berat \% sisa yang tinggal masih tinggi sekitar 5 hingga 15\% (TKKS terawat-AA) dan 18 hingga 30\% (TKKS terawat-EDTA). Ini merujuk kepada pendegradan yang masih belum lengkap disebabkan oleh kestabilan haba yang lebih tinggi berbanding dengan pulpa selulosa yang tidak dirawat (Rajah 6(a) \& 6(b)).

Kedua-dua selulosa TKKS yang diubah suai sama ada dengan AA atau EDTA memerlukan suhu yang lebih tinggi untuk menurunkan peratusan berat berbanding dengan pulpa selulosa TKKS. Hal ini mungkin disebabkan kesan pengubahsuaian oleh kumpulan asid asetik (AA) dan ion logam pengkelatan (EDTA) telah menurunkan bilangan ikatan hidrogen yang terbentuk antara molekul air dan rantaian selulosa TKKS terubah suai, maka struktur selulosa yang lebih stabil terhasil sekaligus telah mendorong peningkatkan kestabilan termalnya (Ahmad et al. 2015; Melo et al. 2015; Wang et al. 2018).

\section{KESIMPULAN}

Secara relatifnya, pulpa selulosa TKKS terawat-EDTA menunjukkan kestabilan termal yang lebih baik berbanding dengan terawat-AA. RSM meramalkan pengubahsuaian selulosa TKKS yang lebih tinggi berlaku menggunakan EDTA mengikut parameter pengesteran yang optimum. Kajian ini penting untuk penghasilan atau pemilihan agen pengubahsuaian dan meramalkan parameter optimum yang akan memberi kesan lebih signifikan terhadap selulosa. Hasil kajian ini berpotensi besar diguna pakai untuk pengubahsuaian biobahan bersumberkan biojisim bagi aplikasi rawatan sisa air.

\section{PENGHARGAAN}

Penulis ingin mengucapkan terima kasih atas pembiayaan daripada geran penyelidikan Kementerian Pengajian Tinggi Malaysia FRGS/1/2018/STG07/UKM/01/1 dan Universiti Kebangsaan Malaysia atas sokongan dan kemudahan sepanjang projek penyelidikan ini.

\section{RUJUKAN}

Abd Wafti, N.S., Lau, H.L.N., Loh, S.K., Aziz, A.A., Ab Rahman, Z. \& May, C.Y. 2017. Activated carbon from oil palm biomass as potential adsorbent for palm oil mill effluent treatment. Journal of Oil Palm Research 29(2): 278-290.

Ahluwalia, S.S. \& Goyal, D. 2007. Microbial and plant derived biomass for removal of heavy metals from wastewater. Bioresource Technology 98(12): 2243-2257.

Ahmad, M., Ahmed, S., Swami, B.L. \& Ikram, S. 2015. Adsorption of heavy metal ions: Role of chitosan and cellulose for water treatment. International Journal of Pharmacognosy 2(6): 280-289.

Ahmad, R., Hamid, R. \& Osman, S.A. 2019. Physical and chemical modifications of plant fibres for reinforcement in cementitious composites. Advances in Civil Engineering 2019: Article ID. 5185806.

Anuar, N.I.S., Zakaria, S., Gan, S., Chia, C.H., Wang, C. \& Harun, J. 2019. Comparison of the morphological and mechanical properties of oil Palm EFB fibres and kenaf fibres in nonwoven reinforced composites. Industrial Crops and Products 127: 55-65.

Asghar, A., Raman, A.A.A. \& Daud, W.M.A.W. 2015. Advanced oxidation processes for in situ production of hydrogen peroxide/hydroxyl radical for textile wastewater treatment: 
A review. Journal of Cleaner Production 87: 826-838.

Azamkamal, F., Zakaria, S., Gan, S. \& Kaco, H. 2018. Chemical and thermal studies on esterification of EDTA with raw cellulose and mercerized cellulose EFB. In AIP Conference Proceedings 1940(1): 020016.

Baiya, C., Nannuan, L., Tassanapukdee, Y., Chailapakul, O. \& Songsrirote, K. 2019. The synthesis of carboxymethyl cellulose based hydrogel from sugarcane bagasse using microwave assisted irradiation for selective adsorption of copper (II) ions. Environmental Progress \& Sustainable Energy 38(1): 157-165.

Bewick, V., Cheek, L. \& Ball, J. 2003. Statistics review 7: Correlation and regression. National Center for Biotechnology Information 7: 451-459.

Daneshfozouna, S., Nazirb, M.S., Abdullaha, B. \& Abdullaha, M.A. 2014. Surface modification of celluloses extracted from oil palm empty fruit bunches for heavy metal sorption. Chemical Engineering 37: 679-683.

de Carvalho Benini, K.C.C., Pereira, P.H.F., Cioffi, M.O.H. \& Voowald, H.J.C. 2017. Effect of acid hydrolysis conditions on the degradation properties of cellulose from Imperata Brasiliensis fibers. Procedia Engineering 200: 244-251.

Englert, C., Schwenke, A.M., Hoeppener, S., Weber, C. \& Schubert, U.S. 2016. Microwave-assisted polymer modifications. In Microwave-Assisted Polymer Synthesis, edited by Hoogenboom, R., Schubert, U.S. \& Wiesbrock, F. Switzerland: Springer Nature. hlm. 209-240.

Fathilah, W.F.W. \& Othaman, R. 2019. Electrospun cellulose fibres and applications. Sains Malaysiana 48(7): 1459-1472.

Gan, S., Zakaria, S., Chia, C.H., Padzil, F.N.M. \& Ng, P. 2015. Effect of hydrothermal pretreatment on solubility and formation of kenaf cellulose membrane and hydrogel. Carbohydrate Polymers 115: 62-68.

Hamzah, N., Tokimatsu, K. \& Yoshikawa, K. 2019. Solid fuel from oil palm biomass residues and municipal solid waste by hydrothermal treatment for electrical power generation in Malaysia: A review. Sustainability 11(4): 1060.

Ibrahim, I., Hassan, M.A., Abd-Aziz, S., Shirai, Y., Andou, Y., Othman, M.R., Ali, A.A.M. \& Zakaria, M.R. 2017. Reduction of residual pollutants from biologically treated palm oil mill effluent final discharge by steam activated bioadsorbent from oil palm biomass. Journal of Cleaner Production 141: 122-127.

Jandura, P., Riedl, B. \& Kokta, B.V. 2000. Thermal degradation behavior of cellulose fibers partially esterifed with some long chain organic acids. Polymer Degradation and Stability 70: 387-394.

Khalid, W.E.F.W., Heng, L.Y. \& Arip, M.N.M. 2018. Surface modification of cellulose nanomaterial for urea biosensor application. Sains Malaysiana 47(5): 941-949.

Le Normand, M., Moriana, R. \& Ek, M. 2014. Isolation and characterization of cellulose nanocrystals from spruce bark in a biofinery perspective. Carbohydrate Polymers 111: 979-987.

Mazlan, N.S.N., Zakaria, S., Gan, S., Hua, C.C. \& Baharin, K.W. 2019. Comparison of regenerated cellulose membrane coagulated in sulphate-based coagulant. Cerne 25(1): 18-24.

Melo, D., Oliveira, S.N., de Freitas Barros, F.C., Raulino, G.S.C., Vidal, C.B. \& Nascimento, R.F. 2016. Chemical modifications of lignocellulosic materials and their application for removal of cations and anions from aqueous solutions. Journal of Applied Polymer Science 133: 43286.

Mudhoo, A., Garg, V.K. \& Wang, S. 2012. Removal of heavy metals by biosorption. Environmental Chemistry Letters 10(2): 109-117.

Pan, Z., Wang, K., Wang, Y., Tsiakaras, P. \& Song, S. 2018. Insitu electrosynthesis of hydrogen peroxide and wastewater treatment application: A novel strategy for graphite felt activation. Applied Catalysis B: Environmental 237: 392400.

Qaiser, A.A. \& Hyland, M.M. 2010. X-ray photoelectron spectroscopy characterization of polyaniline-cellulose ester composite membranes. In Materials Science Forum. Trans Tech Publications Ltd. 657: 35-45.

Rahayu, D.E., Wirjodirdjo, B. \& Hadi, W. 2019. Availability of empty fruit bunch as biomass feedstock for sustainability of bioenergy product (system dynamicapproach). In AIP Conference Proceedings. AIP Publishing LLC. 2194(1): 020095.

Rantuch, P. \& Chrebet, T. 2014. Thermal decomposition of cellulose insulation. Cellulose Chemical Technology 48(56): 461-467.

Razali, N.F., Chin Hua, C., Zakaria, S., Sajab, M.S., Tobe, T. \& Tsuda, M. 2020. Penyahwarnaan efluen kilang minyak kelapa sawit (POME) melalui proses pengoksidaan fenton secara berterusan menggunakan limonit sebagai pemangkin. Sains Malaysiana 49(1): 69-74.

Saad, M.J., Chin Hua, C., Zakaria, S., Sajab, M.S. \& Misran, S. 2020. Malaysia rice wastes for activated carbon production. In Proceeding - 9th Kuala Lumpur International Agriculture, Forestry and Plantation Conference (KLIAFP9). hlm. 20-26.

Sajab, M.S., Chia, C.H., Chan, C.H., Zakaria, S., Kaco, H., Chook, S.W. \& Chin, S.X. 2016. Bifunctional graphene oxide - cellulose nanofibril aerogel loaded with Fe (III) for the removal of cationic dye via simultaneous adsorption and Fenton oxidation. RSC Advances 6(24): 19819-19825.

Sajab, M.S., Chia, C.H., Zakaria, S. \& Sillanpää, M. 2017. Adsorption of heavy metal ions on surface of functionalized oil palm empty fruit bunch fibers: single and binary systems. Sains Malaysiana 46(1): 157-165.

Salleh, K.M., Zakaria, S., Sajab, M.S., Gan, S., Chia, C.H., Jaafar, S.N.S. \& Amran, U.A. 2018. Chemically crosslinked hydrogel and its driving force towards superabsorbent behaviour. International Journal of Biological Macromolecules 118: 1422-1430.

Samiran, N.A., Jaafar, M.N.M., Chong, C.T. \& Jo-Han, N. 2015. A review of palm oil biomass as a feedstock for syngas fuel technology. Jurnal Teknologi (Sciences \& Engineering) 72: 13-18.

Sakaguchi, M., Ohura, T., Iwata, T., Takahashi, S., Akai, S., Kan, T., Murai, H., Fujiwara, M., Watanabe, O. \& Narita, M. 2010. 
Diblock copolymer of bacterial cellulose and poly (methyl methacrylate) initiated by chain-end-type radicals produced by mechanical scission of glycosidic linkages of bacterial cellulose. Biomacromolecules 11(11): 3059-3066.

Senna, A.M., Novack, K.M. \& Botaro, V.R. 2014. Synthesis and characterization of hydrogels from cellulose acetate by esterification crosslinking with EDTA dianhydride. Carbohydrate Polymers 114: 260-268.

Senna, A.M., do Carmo, J.B., da Silva, J.M.S. \& Botaro, V.R. 2015. Synthesis, characterization and application of hydrogel derived from cellulose acetate as a substrate for slowrelease NPK fertilizer and water retention in soil. Journal of Environmental Chemical Engineering 3(2): 996-1002.

Sheltami, R.M., Kargarzadeh, H. \& Abdullah, I. 2015. Effects of silane surface treatment of cellulose nanocrystals on the tensile properties of cellulose-polyvinyl chloride nanocomposite. Sains Malaysiana 44(6): 801-810.

Smith, B.C. 2018. The $\mathrm{C}=\mathrm{O}$ bond, part III: Carboxylic acids. Spectroscopy 33(1): 14-20.

Stevulova, N., Cigasova, J., Estokova, A., Terpakova, E., Geffert, A., Kacik, F., Singovszka, E. \& Holub, M. 2014. Properties characterization of chemically modified hemp hurds. Materials 7(12): 8131-8150.

Wang, X., Tang, C., Wang, Q., Lu, Y. \& Liu, X. 2018. Thermal stability improvement of polysiloxane-grafted insulating paper cellulose in micro-water environment. AIP Advances 8(10): 105007.

Yagyu, H., Saito, T., Isogai, A., Koga, H. \& Nogi, M. 2015. Chemical modification of cellulose nanofibers for the production of highly thermal resistant and optically transparent nanopaper for paper devices. ACS Applied Materials and Interfaces 7(39): 22012-22017.

Yan, E.Y.C., Zakaria, S., Chia, C.H. \& Boku, T. 2017. Bifunctional regenerated cellulose membrane containing $\mathrm{TiO}_{2}$ nanoparticles for absorption and photocatalytic decomposition. Sains Malaysiana 46(4): 637-644.
Yao, Y. \& Wang, H. 2018. An overview on chemical modification of cellulose. Materials Reports 32(19): 3478-3488.

Zhou, L., Ke, K., Yang, M.B. \& Yang, W. 2020. Recent progress on chemical modification of cellulose for high mechanicalperformance poly (lactic acid)/cellulose composite: A short review. Composites Communications 2020: 100548.

Marhaini Mostapha, Fatihah Azamkamal, Kushairi Mohd Salleh*, Umar Adli Amran \& Sarani Zakaria

Bioresources \& Biorefinery Laboratory

Department of Applied Physics

Faculty of Science and Technology

Universiti Kebangsaan Malaysia

43600 UKM Bangi, Selangor Darul Ehsan

Malaysia

Marhaini Mostapha

Higher Institution Centres of Excellence

Center for Biofuels and Biochemical Research

Institute of Self-Sustainable Building

Universiti Teknologi PETRONAS

32610 Bandar Seri Iskandar, Perak Darul Ridzuan

Malaysia

Sinyee Gan

Malaysian Palm Oil Board

6 Persiaran Institusi, Bandar Baru Bangi

43000 Kajang, Selangor Darul Ehsan

Malaysia

*Pengarang untuk surat-menyurat; email: kushairisalleh@ukm. edu.my

Diserahkan: 8 Januari 2021

Diterima: 2 April 2021 